\title{
PENGEMBANGAN PERANGKAT PEMBELAJARAN BERBASIS PENDIDIKAN MATEMATIKA REALISTIK TERHADAP KEMAMPUAN SPASIAL DAN MOTIVASI SISWA SMP
}

\author{
Shulha Kynanda Putri ${ }^{1}$, Hasratuddin ${ }^{2}$, Edi Syahputra ${ }^{2}$
}

\begin{abstract}
ABSTRAK
Penelitian ini bertujuan untuk menemukan: (1) perangkat pembelajaran yang efektif berbasis PMR terhadap kemampuan spasial siswa di SMPN 2 Pulo Bandring; (2) perangkat pembelajaran yang efektif berbasis PMR terhadap motivasi siswa di SMPN 2 Pulo Bandring. Penelitian ini merupakan penelitian pengembangan dengan menggunakan model pengembangan Dick dan Carey. Perangkat yang dikembangkan berupa RPP, LKS dan Buku Siswa. Subjek penelitian ini adalah siswa SMP Negeri 2 Pulo Bandring kelas IX. Berdasarkan pengembangan perangkat pembelajaran yang efektif diperoleh berdasarkan indikator keefektifan. Dari hasil penelitian diperoleh bahwa: (1) ketuntasan klasikal mencapai $90 \%$ yakni telah memenuhi kriteria ketuntasan yakni $285 \%$ siswa mencapai KKM; (2) ketuntasan tujuan pembelajaran rata-rata mencapai $77,24 \%$ yakni telah memenuhi kriteria ketuntasan yakni $275 \%$ dari skor maksimum tiap butir soal; (3) respon siswa terhadap pembelajaran diperoleh rata-rata 94,8\%; (4) waktu pembelajaran dalam penelitian tidak berbeda jauh dengan waktu pembelajaran biasa.
\end{abstract}

Kata Kunci: Development research, Dick \& Carey Model, Realistic Mathematics Education, Spatial Ability, Motivation.

\section{PENDAHULUAN}

Salah satu pengetahuan yang memiliki peranan penting dalam meningkatkan sumber daya yang berkualitas adalah pendidikan matematika. Penyebab utama pentingnya pendidikan matematika adalah kemampuan siswa dalam matematika merupakan landasan dan wahana pokok yang menjadi syarat mutlak yang harus dikuasai untuk melatih kemampuan siswa secara teratur, sistematis, bertanggung jawab dan memiliki kepribadian yang baik serta keterampilan untuk dapat menyelesaikan persoalan dalam kehidupan sehari-hari. Hadi (2017:11) menyatakan bahwa "Pendidikan matematika di tanah air saat ini sedang mengalami perubahan paradigma. Terdapat kesadaran yang kuat, terutama di kalangan pengambil kebijakan, untuk memperbaharui pendidikan matematika".

Paradigma baru dalam pendidikan matematika lebih menekankan kepada siswa yang harus aktif dalam melatih dan mengembangkan kemampuannya. Melalui paradigma baru tersebut diharapkan agar siswa aktif dalam belajar, berdiskusi dan menyampaikan gagasan dan menerima ide dari orang lain serta memiliki kepercayaan diri yang tinggi. Saat ini banyak upaya berkesinambungan yang dilakukan pemerintah dalam meningkatkan mutu pengajaran dan pembelajaran matematika. Upaya tersebut dapat kita lihat melalui pembaharuan kurikulum dan juga penyediaan perangkat pembelajaran yang mendukung seperti

${ }^{1}$ Corresponding Author: Shulha Kynanda Putri

Program Magister Pendidikan Matematika, Universitas Negeri Medan, Medan, 20221, Indonesia

E-mail: akindy66@gmail.com

${ }^{2}$ Co-Author: Hasratuddin \& Edi Syahputra

Program Studi Pendidikan Matematika,Universitas Negeri Medan, Medan, 20221, Indonesia silabus, rencana pelaksanaan pembelajaran, buku siswa sampai penyediaan alat peraga dan pelatihan profesi bagi guru matematika.

Sukmadinata (2012:164) menyatakan bahwa "Penelitian dan pengembangan adalah sebuah strategi atau metode penelitian yang cukup ampuh untuk memperbaiki praktik". Salah satu upaya yang dapat dilakukan saat ini adalah guru mampu menyusun perangkat pembelajaran yang efektif. Artinya, perangkat pembelajaran yang memenuhi kriteria efektif. Kemudian perangkat pembelajaran tersebut dapat dikembangkan oleh guru untuk meningkatkan kualitas pendidikan matematika.

Hal tersebut begitu pentingnya karena tanpa adanya perangkat pembelajaran akan sulit bagi guru untuk meningkatkan efektivitas pembelajaran. Begitu juga halnya dengan siswa, tanpa perangkat pembelajaran siswa akan kesulitan untuk menyesuaikan diri dalam belajar. Melalui hasil penelitian Azwar dan Surya (2017) dimana perangkat pembelajaran yang dikembangkan telah memenuhi efektivitas pembelajaran matematika. Efektivitas ini dapat dilihat dari ketuntasan siswa dalam belajar, aktivitas siswa dalam proses pembelajaran baik, keterlaksanaan sintaks pembelajaran di kelas baik, serta respon siswa terhadap perangkat dan pembelajaran di kelas positif.

Agar diperoleh hasil perangkat pembelajaran yang memenuhi kriteria efektif seperti yang telah disebutkan dalam penelitian di atas maka diperlukan pemilihan model pembelajaran yang tepat. Sembiring (2010:12) berpendapat bahwa "Pendekatan Matematik Realistik (PMR) merupakan suatu gerakan untuk mereformasi pendidikan matematika di Indonesia. Jadi bukan hanya suatu metode pembelajaran matematika, tapi juga suatu usaha melakukan transformasi sosial. Karakteristik dari

Pengembangan Perangkat Pembelajaran Berbasis Pendidikan Matematika Realistik Terhadap Kemampuan Spasial dan 
pendekatan tersebut adalah: (1) siswa lebih aktif berfikir, (2) konteks dan bahan ajar terkait langsung dengan lingkungan sekolah dan siswa, (3) peran guru lebih aktif dalam merancang bahan ajar dan kegiatan kelas".

Shadiq (2010:7) menambahkan bahwa "Pendidikan Matematika Realistik merupakan suatu pendekatan pembelajaran matematika yang mengungkapkan pengalaman dan kejadian yang dekat dengan siswa sebagai sarana untuk memahamkan persoalan matematika. Dalam PMR dunia nyata (real world) dapat dimanfaatkan sebagai titik awal pengembangan ide dan konsep mtematika. Melalui penerapan PMR diharapkan mampu menekankan keterampilan pada siswa dan memecahkan masalah yang berkaitan dengan kehidupan sehari - hari".

Menurut Safitri, Surya, Syahputra dan Simbolon (2017:95) "Realistic mathematic education (RME) approach come from contextual issues, in this situastion student ashould has the active role in learning activities, while teacher plays as facilitator". Pendapat tersebut bermakna bahwa Pendekatan Matematika Realistik berasal dari masalah kontekstual, dimana dalam situasi ini siswa harus aktif dalam pembelajaran dan guru bertindak sebagai fasilitator.

Hadi (2017:37) juga mengakui bahwa "Konsep PMR sejalan dengan kebutuhan untuk memperbaiki pendidikan matematika di Indonesia yang didominasi oleh persoalan bagaimana meningkatkan pemahaman siswa tentang matematika dan mengembangkan daya nalar". Hal ini merupakan suatu kelebihan sehingga setiap guru matematika di Indonesia harus tahu bahwa PMR ini sangat layak untuk digunakan dalam proses pembelajaran.

Berdasarkan hal tersebut di atas, besar manfaat PMR yang bisa didapatkan baik oleh guru maupun siswa. Oleh karena itu, pengembangan perangkat akan menjadi efektif bila menggunakan pendekatan pembelajaran realistik. Karena PMR merupakan dunia nyata dimana masalah-masalah matematika yang dihadapi siswa juga berasal dari dunia nyata siswa. Hal ini tentu akan mempermudah siswa dalam menafsirkan konsep matematik.

Bertolak dari pendapat di atas, ironisnya saat ini banyak siswa yang tidak mampu menyelesaikan masalah matematik yang dikaitkan dalam kehidupan hari-hari. Di sisi lain, kenyataannya guru belum melakukan persiapan yang matang sebelum mengajar. Hal ini juga diperkuat dengan pendapat Ritonga, Surya dan Syahputra (2017:43) bahwa "But the reality of the field that there are still many teachers who have not designed the learning tool well. Often found learning devices only limited to the terms only for administrative completeness".

Menyadari pentingnya pembelajaran realistik, diharapkan dapat meningkatkan kemampuan matematika siswa. Maka dari itu, diperlukan adanya pembelajaran matematika yang lebih banyak melibatkan siswa secara aktif dalam proses pembelajaran. Hal ini dapat terwujud melalui suatu bentuk pengembangan perangkat pembelajaran yang dirancang melibatkan keaktifan siswa dalam merespon kemampuan matematiknya.

Pieronkiewicz (2014) menyatakan bahwa "Mathematics as a school subject raises a lot of negative emotions among students and their parents. It is seen as difficult, detached from reality, full of useless in everyday life definitions and theorems". Dikatakan bahwa matematika sebagai subjek di sekolah banyak menimbulkan emosi negatif di kalangan siswa dan orang tua mereka. Matematika dipandang sulit, terlepas dari kenyataan, penuh dengan definisi dan teorema yang tak berguna dalam kehidupan sehari-hari. Masalah matematika yang abstrak memang menjadi momok yang paling ditakuti siswa.

Menurut Athar (2012) "Masalah abstraknya objekobjek matematika akan menjadi lebih rumit jika proses pembelajaran tidak tepat dengan siswa. Pembelajaran yang tidak tepat akan membawa kebosanan yang akan menjadikan momok ketidaksukaan matematika pada siswa. Untuk itu harus dilakukan dengan cara merealistikkan objek matematika dan melaksanakan satu pembelajaran yang melibatkan keaktifan siswa".

Matematika merupakan sarana untuk menumbuhkan kemampuan matematis siswa. Untuk menghindari kesan negatif terhadap matematika, guru dituntut agar menciptakan proses pembelajaran yang menyenangkan, sehingga siswa memiliki dorongan yang kuat untuk belajar. Hasratuddin (2014:33) mengungkapkan bahwa "Kemampuan-kemampuan yang dapat diperoleh dari matematika antara lain; a) kemampuan berhitung, b) kemampuan mengamati dan membayangkan bangunan-bangunan geometris yang ada di alam beserta dengan sifat-sifat keruangan (spatial properties) masing-masing .... Kemampuan pemecahan masalah dalam berbagai situasi”.

Dengan kemampuan-kemampuan tersebut, siswa akan mampu mengontrol aktivitas yang terjadi pada dirinya sendiri. Aktivitas belajar yang lebih terarah akan menghasilkan hasil belajar yang lebih optimal. Misalnya saja dalam hal kemampuan spasial matematika siswa. Dalam hal ini, sangat memungkinkan bagi siswa untuk mencoba berbagai macam strategi dalam memahami suatu konsep. Menurut Noviani, Syahputra dan Murad (2017): "The concept of spatial thinking is interesting enough to be discussed considering many previous studies states that the children find many difficulties to understand the object or the image of the geometry".

Hal diatas sependapat dengan penelitian Syahputra (2013) bahwa: "Kemampuan spasial yang baik akan menjadikan siswa mampu mendeteksi hubungan dan perubahan bentuk bangun geometri”. Syahputra (2013) menambahkan "Demikian pentingnya kemampuan spasial ini sehingga kita semua terutama para guru dituntut untuk memberikan perhatian yang lebih dari cukup agar kemampuan spasial diajarkan dengan sungguh-sungguh sesuai dengan amanat kurikulum”. 
Quintero, Salinas, Mendivil dan Ramirez (2015) berpendapat bahwa "Spatial ability is the basic perception skill for recognizing and understanding objects in the physical world". Dari pernyataan tersebut ditekankan bahwa kemampuan spasial merupakan keterampilan pengetahuan dasar untuk mengenali dan memahami objek yang ada di alam semesta. Untuk itu, kemampuan spasial perlu dihadirkan secara intensif agar siswa terlibat aktif dalam pembelajaran matematika.

Selain hal tersebut di atas, kemampuan spasial siswa diperkuat berdasarkan hasil penelitian Oktaviana (2016:351) bahwa "Kemampuan spasial memiliki hubungan positif terhadap kemampuan matematika ataupun prestasi belajar siswa. Semakin baik kemampuan spasial siswa maka prestasi belajar matematika juga akan semakin baik". Berkaitan dengan uraian tersebut, kemampuan spasial mempunyai tingkatan tertinggi agar siswa mampu menggunakan kecerdasannya.

Prestasi pembelajaran di sekolah tak hanya ditentukan oleh kemampuan kognitif siswa, tetapi juga ditentukan oleh kemampuan afektifnya. Kemampuan afektif yang dimaksud dalam penelitian ini adalah motivasi belajar. Tidak dapat dipungkiri bahwa manfaat matematika untuk manusia sangat besar, sehingga subjek matematika menjadi perhatian dalam hal ini untuk mempelajari matematika diperlukan dorongan yang kuat baik dari dalam diri siswa maupun dorongan dari luar diri siswa. Dorongan ini disebut dengan motivasi belajar matematika yang diukur dari kemampuan spasial matematika siswa.

Menurut Tapantoko (2011: 4) bahwa "Motivasi belajar merupakan hal yang penting dan perlu diketahui setiap guru dalam peranannya yaitu dapat menumbuhkan gairah, merasa senang dan semangat untuk belajar bagi siswa. Motivasi berkaitan dengan sejumlah keterlibatan siswa dalam aktivitas di kelas seperti dorongan untuk melakukan sesuatu berdasarkan tujuan tertentu, kebiasaan-kebiasaan, kebutuhankebutuhan dan hasrat tertentu".

Berdasarkan pendapat tersebut diatas dapat dinyatakan bahwa motivasi merupakan tenaga penggerak atau pendorong seseorang untuk melakukan sesuatu sesuai dengan tujuan yang telah ditetapkannya. Motivasi belajar adalah sesuatu hal yang sangat dibutuhkan oleh seorang guru untuk memberikan dorongan kepada siswa agar dapat mencapai tujuan pembelajaran.

Namun, perkembangan dalam pembelajaran matematika banyak mengalami hambatan. Abdurrahman (dalam Aufa dan Saragih, 2016:232) berpendapat bahwa "Mathematics is one of the subjects taught at every level of education, starting from early childhood education to the level of Higher Education. Mathematics is also the science that underlies the development of science and technology, so that mathematics is seen as a structured and integrated science, the study of patterns and relationships, and the science of thinking to understand the world around". Oleh karena itu, sebaiknya guru menghindari metode ceramah dan mampu menciptakan dan mengembangkan pengalaman belajar yang mendorong kemampuan spasial matematika dan motivasi siswa.

\section{KAJIAN TEORITIS \\ Kemampuan Spasial dalam Matematika}

Gardner (1989:6) menemukan tujuh jenis kecerdasan yang dimiliki manusia, yaitu (1) logicalmathematical; (2) linguistic; (3) musical; (4) spatial; (5) bodily-kinesthetic; (6) interpersonal; (7) intrapersonal. Ketujuh kecerdasan itu dimiliki oleh manusia, bahkan tidak jarang ada manusia yang bisa memaksimalkan keseluruhan dari kecerdasan tersebut.

Hubungan kecerdasan tersebut dengan siswa yakni kecerdasan majemuk sudah ada dalam diri siswa. Artinya kecerdasan majemuk sudah berada pada sistem pendidikan di sekolah siswa saat ini. Alkalbani dan Alwahaibi (2015:575) menegaskan bahwa "As learners are the most important element of any educational system, dealing with them should not be random. Their needs, learning styles, strengths and weakness should be addressed and recognized in order to have effective and meaningful learning. MI is a new model of learning that helps students to learn effectively".

Pendapat di atas menunjukkan bahwa siswa merupakan unsur terpenting dari sistem pendidikan, hubungan keduanya tidak terpisahkan. Kebutuhan, gaya belajar, kekuatan dan kelemahan siswa harus diatasi dan dikenali untuk mendapatkan pembelajaran yang efektif dan berarti. Multiple Intelligence adalah modal bagi siswa untuk mengasah kecerdasannya dan merupakan pembelajaran baru yang membantu siswa untuk belajar secara efektif. Dari uraian di atas, salah satu jenis kecerdasan yang dimiliki siswa adalah kecerdasan spasial. Kecerdasan spasial siswa dapat kita lihat dari materi-materi pembelajaran matematika di sekolah.

Hasratuddin (2014) bahwa "Matematika mempunyai potensi yang besar untuk memberikan berbagai macam kemampuan, dan sikap yang diperlukan oleh manusia agar ia bisa hidup secara cerdas (Intelligent) dalam lingkungannya". Berdasarkan pendapat-pendapat tersebut di atas maka kemampuan spasial berhubungan dengan kecerdasan yang dimiliki oleh siswa.

Hasratuddin (2014) menambahkan bahwa "Salah satu kemampuan-kemampuan yang dapat diperoleh adalah kemampuan mengamati dan membayangkan bangunan-bangunan geometris yang ada di alam beserta dengan sifat-sifat keruangan (spatial properties) masing-masing objek tersebut". Kemampuan spasial merupakan salah satu aspek dari kognisi. Kemampuan membayangkan suatu bentuk nyata dan kemudian memecahkan berbagai masalah yang berhubungan dengan kemampuan ini adalah hal yang menonjol pada jenis kemampuan spasial ini. 
Vol. 13, No.1, Juni 2020

Maier (1998:64) membagi kemampuan spasial menjadi lima aspek yaitu: Spatial Perception, Visualisation, Mental Rotation, Spatial Relation dan Spatial Orientation. Melalui aspek kemampuan spasial inilah terjadi proses berfikir siswa dalam menjawab masalah matematika yang diberikan.

\section{Motivasi Belajar}

Colomeischi dan Colomeischi (2014:745) mengungkapkan bahwa "Learning mathematics became a challenge for most of the student. Either lack of motivation or learned hopelessness make many student to say 'I'm not good in math' before they even try to solve mathematical problems".

Motivasi adalah sesuatu yang dibutuhkan untuk melakukan aktivitas. Ketika seseorang berbuat sesuatu tentu mempunyai suatu tujuan atau bisa dikatakan seseorang melakukan sesuatu dengan maksud, tujuan dan motivasi tertentu. Begitu juga dengan siswa dalam belajar memerlukan motivasi terus menerus untuk memusatkan pikiran dan perhatiannya kepada materi atau bahan-bahan yang diberikan kepada mereka.

Definisi motivasi oleh Suranto (2015) adalah "Motor penggerak atau dorongan dalam perbuatan, sehingga siswa yang memiliki motivasi akan tergerak dalam belajar". Menurut Sardiman (dalam Sabrida, 2016:24) motivasi adalah "Keseluruhan daya penggerak di diri siswa yang menimbulkan kegiatan belajar dan menjamin kelangsungan kegiatan belajar, sehingga tujuan yang dikehendaki siswa tercapai”. Menurut pendapat diatas dapat disimpulkan bahwa motivasi adalah suatu alat penggerak agar siswa tetap bersemangat dalam belajar dan mencapai tujuan belajar.

Menurut Tohidi dan Jabbari (2012) konsep motivasi dibedakan menjadi dua yakni motivasi instrinstik dan ekstrinstik. Keduanya saling berinteraksi dalam mencapai prestasi belajar. Motivasi instrinstik merupakan motivasi yang bersumber dari kebutuhan dan tujuan-tujuan siswa itu sendiri. Motivasi instrinstik yakni berupa hasrat dan keinginan berhasil, dorongan kebutuhan belajar dan harapan akan cita-cita. Sedangkan motivasi ekstrinstik merupakan faktor yang timbul dari pengaruh luar siswa, yakni berupa adanya penghargaan, lingkungan belajar yang kondusif dan kegiatan belajar yang menarik.

\section{Pendekatan Pendidikan Matematika Realistik}

Vygotsky (1978) menyatakan penggunaan konteks dunia nyata sangat berarti bagi pembelajaran siswa, karena mereka langsung terlibat dalam situasi nyata. Sehingga siswa tertarik dalam proses pembelajaran. Veloo dan Zubainur (2014:309) menyatakan bahwa "Indonesian Realistic Mathematics Education (IRME) was aimed to make learning Mathematics more interesting and meaningful for students by introducing teaching this subject through contextual problems were the problems were in the student's knowledge and experience"
Sejalan dengan konsep asalnya, PMR dikembangkan dari tiga prinsip dasar yang mengawali RME. Menurut Gravemeijer (1994) ketiga prinsip tersebut adalah: (1) penemuan kembali terbimbing, (2) fenomena pembelajaran, dan (3) model-model yang dibangun sendiri. Ketiga prinsip PMR tersebut dikolaborasikan dalam pembelajaran sehingga siswa tidak gampang bosan.

Menurut De Lange (dalam Shadiq, 2010:11) karakteristik PMR secara umum adalah: penggunaan konteks dalam eksplorasi fenomenologis, penggunaan model untuk mengontruksi konsep, penggunaan kreasi dan kontribusi siswa, sifat aktif dan interaktif dalam proses pembelajaran, dan Kesalingterkaitan (intertwinement) antara aspek-aspek atau unit-unit matematika. Dengan adanya karakteristik dari pendekatan matematika realistik tersebut yang akan digunakan dalam penelitian ini diharapkan dapat mencapai tujuan yang diinginkan.

\section{Perangkat Pembelajaran}

Perangkat pembelajaran yang dikembangkan adalah RPP, Buku Siswa dan LKS, serta tes kemampuan spasial dan angket motivasi siswa. Perangkat pembelajaran yang dikembangkan berbasis PMR tersebut menggunakan model pengembangan Dick \& Carey.

\section{METODE PENELITIAN}

Penelitian ini dilaksanakan di SMP Negeri 2 Pulo Bandring. Kelas IX Pada Tahun Ajaran 2018/2019, pada semester 1 (ganjil). Adapun alasan pemilihan lokasi penelitian ini adalah karena pentingnya kemampuan spasial dalam matematika siswa SMP, belum adanya penelitian sejenis di sekolah tersebut yaitu penelitian mengenai pengembangan perangkat pembelajaran terhadap kemampuan spasial dan motivasi siswa yang dilakukan di SMP Negeri 2 Pulo Bandring.

Penelitian ini menggunakan model pengembangan Dick \& Carey. Jenis penelitian ini bertujuan untuk menemukan perangkat pembelajaran yang efektif terhadap kemampuan spasial dan motivasi siswa dalam penerapan model pembelajaran PMR. Subjek dalam penelitian ini adalah kelas IX SMP Negeri 2 Pulo Bandring

Mekanisme yang digunakan dalam penelitian ini meliputi tahap uji coba perangkat pembelajaran. Setiap uji coba dilakukan pada kelas yang berbeda untuk menemukan perangkat pembelajaran yang efektif terhadap kemampuan spasial dan motivasi. Sebelum perangkat diuji coba dilakukan yaitu (1) tahap persiapan alat belajar dan instrumen penelitian; (2) tahap validasi dan pengujian alat dan penelitian studi instrumen; (3) tahapan pelaksanaan penelitian dan analisis data. Setiap tahap dirancang sedemikian rupauntuk mendapatkan data yang valid untuk tujuan penelitian. 


\section{HASIL PENELITIAN \\ Uji Coba I}

Berdasarkan uji coba I didapatkan hasil pengembangan perangkat berbasis PMR yang belum efektif. Yakni dua dari empat indikator keefektifan yaitu ketuntasan klasikal dan ketercapaian tujuan pembelajaran belum tercapai, meskipun respon positif siswa dan waktu pembelajaran sudah tercapai. Maka, dilakukan uji coba II di kelas yang berbeda dengan melihat kelemahan-kelemahan perangkat pembelajaran pada uji coba I.

\section{Uji Coba II}

Berdasarkan uji coba II ditemukan perangkat pembelajaran yang sudah efektif terhadap kemampuan spasial dan motivasi siswa dilihat dari empat indikator keefektifan.

\section{a. Ketuntasan klasikal}

Ketuntasan klasikal siswa ditunjukkan pada Tabel 1.

Tabel 1 Tingkat Ketuntasan Kemampuan Spasial Siswa

\begin{tabular}{|c|c|c|}
\hline Kategori & $\begin{array}{c}\text { Jumlah } \\
\text { Siswa }\end{array}$ & $\begin{array}{c}\text { Presentase } \\
\text { Ketuntasan } \\
\text { Klasikal }\end{array}$ \\
\hline Tuntas & 27 & $90 \%$ \\
\hline Tidak Tuntas & 3 & $10 \%$ \\
\hline Jumlah & 30 & $100 \%$ \\
\hline Rata-rata Kelas & 77,03 & \\
\hline
\end{tabular}

Berdasarkan Tabel 1 tersebut maka diperoleh bahwa 30 siswa kelas IX, 27 orang siswa tuntas secara klasikal, 3 orang tidak tuntas secara klasikal. Sehingga rata-rata kelas adalah 77,03. Berdasarkan ketuntasan klasikal yakni lebih dari atau sama dengan 85 siswa tuntas secara klasikal. Sedangkan untuk motivasi siswa dapat dilihat pada Tabel 2.

Tabel 2 Tingkat Ketuntasan Motivasi Siswa

\begin{tabular}{|c|c|c|}
\hline Kategori & $\begin{array}{c}\text { Jumlah } \\
\text { Siswa }\end{array}$ & $\begin{array}{c}\text { Presentase } \\
\text { Ketuntasan } \\
\text { Klasikal }\end{array}$ \\
\hline Tuntas & 26 & $86,7 \%$ \\
\hline Tidak Tuntas & 4 & $13,3 \%$ \\
\hline Jumlah & 30 & $100 \%$ \\
\hline Rata-rata Kelas & 78,11 & \multicolumn{1}{|l}{} \\
\hline
\end{tabular}

Berdasarkan Tabel 2 tersebut maka diperoleh bahwa 30 siswa kelas IX, 26 orang siswa tuntas secara klasikal, 4 orang tidak tuntas secara klasikal. Sehingga rata-rata kelas adalah 78,11. Maka siswa dikatakan tuntas secara klasikal.

\section{b. Ketercapaian tujuan pembelajaran}

Deskripsi ketercapaian tujuan pembelajaran dapat dilihat pada Tabel 3 berikut ini.
Tabel 3 Ketercapaian Tujuan Pembelajaran Posttest Kemampuan Spasial

\begin{tabular}{|c|c|c|c|}
\hline \multirow{2}{*}{ No } & \multirow{2}{*}{$\begin{array}{c}\text { Tujuan } \\
\text { Pembelajaran }\end{array}$} & \multicolumn{2}{|c|}{ Kemampuan Spasial } \\
\hline & & Ketercapaian & Ket \\
\hline 1 & $\begin{array}{l}\text { Menyebutkan } \\
\text { unsur-unsur: jari- } \\
\text { jari/diameter, } \\
\text { tinggi, sisi, alas } \\
\text { dari tabung, } \\
\text { kerucut, bola. }\end{array}$ & $80,61 \%$ & Tercapai \\
\hline 2 & $\begin{array}{l}\text { Mengenal jaring- } \\
\text { jaring bangun } \\
\text { tabung, kerucut, } \\
\text { bola. }\end{array}$ & $75,48 \%$ & Tercapai \\
\hline 3 & $\begin{array}{l}\text { Memecahkan } \\
\text { masalah yang } \\
\text { berkaitan dengan } \\
\text { tabung, kerucut, } \\
\text { bola dengan } \\
\text { menggunakan } \\
\text { rumus luas. }\end{array}$ & $77,78 \%$ & Tercapai \\
\hline 4 & $\begin{array}{l}\text { Memecahkan } \\
\text { masalah yang } \\
\text { berkaitan dengan } \\
\text { tabung, kerucut, } \\
\text { bola dengan } \\
\text { menggunakan } \\
\text { rumus volume. }\end{array}$ & $75,11 \%$ & Tercapai \\
\hline
\end{tabular}

Berdasarkan Tabel 3 terlihat bahwa ketercapaian tujuan pembelajaran pada soal nomor satu diperoleh sebesar $80,61 \%$, ketercapaian tujuan pembelajaran soal nomor dua diperoleh sebesar $75,48 \%$, ketercapaian tujuan pembelajaran soal nomor tiga diperoleh sebesar $77,78 \%$, dan ketercapaian tujuan pembelajaran soal nomor empat diperoleh sebesar 75,11\%. Sesuai dengan kriteria ketercapaian tujuan pembelajaran, dikatakan tujuan pembelajaran tercapai dengan kriteria $\geq 75 \%$ dari skor maksimum tiap butir soal, dengan demikian ketercapaian tujuan pembelajaran pada uji coba II yaitu pada hasil posttest kemampuan spasial sudah tercapai untuk setiap butir soal.

\section{c. Respon Siswa}

Respon siswa terhadap semua aspek terutama terhadap perangkat pembelajaran yaitu pendapat siswa terhadap komponen pembelajaran yang terdiri dari buku siswa, lembar kerja siswa, dan tes kemampuan spasial matematik serta angket motivasi berada di atas $80 \%$. yaitu 94,8\%. Artinya setiap aspek direspon positif oleh siswa.

\section{d. Waktu Pembelajaran}

Hasil pencapaian waktu pembelajaran pada uji coba II adalah tiga kali pertemuan atau 6 x 40 menit, jika dibandingkan dengan pembelajaran biasa yang dilakukan selama ini, tidak terdapat perbedaan antara pencapaian waktu pembelajaran menggunakan perangkat pembelajaran berbasis PMR pada uji coba II 
dengan pencapaian waktu pembelajaran biasa. Dengan demikian pencapaian waktu pembelajaran menggunakan perangkat pembelajaran berbasis PMR pada uji coba II sama dengan pembelajaran biasa yaitu tiga kali pertemuan atau $6 \times 40$ menit. Hal ini sesuai dengan kriteria waktu pembelajaran, yaitu pencapaian waktu pembelajaran minimal sama dengan pembelajaran biasa, dengan demikian pencapaian waktu pembelajaran uji coba II sudah tercapai.

Berdasarkan hasil analisis data uji coba II, diketahui bahwa perangkat pembelajaran yang dikembangkan telah efektif.

\section{PEMBAHASAN}

Hadi (2017:8) menegaskan bahwa Pendekatan Matematika Realistik (PMR) merupakan suatu pendekatan yang menjanjikan dalam pembelajaran matematika. Pendekatan PMR dalam perangkat pembelajaran yang dikembangkan terdiri dari empat tahap, yaitu memahami masalah kontekstual, menyelesaikan masalah kontekstual, membandingkan atau mendiskusikan jawaban dan penemuan pengetahuan. Dalam penelitian ini, masing-masing tahap pendekatan PMR dalam pembelajaran diajukan masalah-masalah kontekstual.

Menurut Syahputra (2013:355), "secara umum, pendekatan Pendidikan Matematika Realistik terdiri dari lima karakteristik yaitu: (1) penggunaan konteks nyata, (2) penggunaan model, (3) pengaitan dalam dan antar topik matematika, (4) penggunaan metode interaktif dan (5) menghargai variasi jawaban dan kontribusi siswa". Syahputra (2013) menambahkan bahwa PMR mampu meningkatkan kemampuan spasial siswa SMP.

Berdasarkan penelitian yang dilakukan oleh Mesarius \& Surya (2017:171) bahwa "With the Realistic Approach of Mathematics students will be associated with direct experience to find solutions to problems related to the subject matter of comparing fractions. It can increase students' understanding of the material'. Penelitian sebelumnya yang mengembangkan perangkat pembelajaran dengan menggunakan model pengembangan Dick and Carey juga dilakukan oleh Marlina (2013:157) dengan mengembangkan sebuah perangkat pembelajaran yang memenuhi kriteria efektif dapat meningkatkan pembelajaran matematika di sekolah.

Kesepuluh langkah Dick and Carey saling berkaitan dan selalu dihubungkan dengan revisi. Seluruh tahap pengembangan perangkat pembelajaran ini selalu mengikuti tahap dari Dick and Carey. Hasil akhir dari pengembangan perangkat pembelajaran ini adalah perangkat pembelajaran matematika berbasis PMR yang dikembangkan efektif. Dalam menentukan keefektifan dilihat dari empat aspek yaitu ketuntasan belajar siswa secara klasikal, ketercapaian tujuan pembelajaran, respon siswa dan waktu pembelajaran.

Zulfahmi, Syahputra dan Fauzi (2017) menyimpulkan bahwa pembelajaran dengan menggunakan pengembangan perangkat pembelajaran mampu memfasillitasi peningkatan kemampuan spasial siswa dalam pembelajaran.

Berdasarkan hasil analisis data, Pertama, ketuntasan belajar siswa secara klasikal berdasarkan hasil analisis posttest uji coba I dan uji coba II diperoleh bahwa kemampuan spasial siswa telah memenuhi kriteria ketuntasan secara klasikal. Lebih dari $80 \%$ siswa mendapatkan nilai $\geq 75$ pada tes spasial yang diberikan dengan kategori tuntas. Tercapainya ketuntasan belajar siswa secara klasikal dalam penelitian ini dikarenakan penggunaan perangkat pembelajaran berbasis PMR mampu menuntun siswa untuk membangun pengetahuannya sendiri sehingga pengetahuan yang diperoleh lebih melekat dalam ingatan.

Kedua, ketercapaian tujuan pembelajaran yang ditekankan dalam penelitian ini adalah siswa memiliki kemampuan spasial yang baik. Ketercapaian tujuan pembelajaran ini dilihat dari keberhasilan siswa dalam menjawab tes kemampuan spasial yang diberikan setelah proses pembelajaran. Berdasarkan hasil analisis uji coba I dan uji coba II, tujuan pembelajaran telah tercapai seluruhnya. Dimana ketercapaian tujuan pembelajaran posttest telah tercapai untuk tiap butir soal.

Ketiga, respon siswa berdasarkan analisis data hasil uji coba I dan uji coba II diperoleh bahwa persentase rata-rata respon siswa pada masing-masing uji coba bernilai positif. Artinya secara keseluruhan siswa merasa terbantu dan senang dengan penggunaan perangkat pembelajaran berbasis PMR yang dilakukan. Siswa yang merespon positif pada uji coba II telah mencapai kategori kriteria yang telah ditentukan yaitu $\geq 80 \%$.

Keempat, waktu pembelajaran berdasarkan pencapaian waktu pembelajaran yang dilakukan selama uji coba I dan uji coba II, lama waktu pembelajaran menggunakan perangkat pembelajaran berbasis PMR sama dengan lama waktu pembelajaran biasa yang dilakukan selama ini.

\section{KESIMPULAN}

Berdasarkan hasil analisis dan pembahasan pada bab IV dan temuan selama pembelajaran berbasis PMR diperoleh beberapa simpulan yang merupakan jawaban atas pertanyaan-pertanyaan yang diajukan dalam rumusan masalah. Simpulan tersebut adalah sebagai berikut:

1. Perangkat pembelajaran matematika berbasis PMR yang dikembangkan adalah efektif dalam meningkatkan kemampuan spasial siswa dengan pemenuhan keempat indikator keefektivan pada uji coba II yaitu:

a. Ketuntasan klasikal mencapai $90 \%$ yakni telah memenuhi kriteria ketuntasan yakni $\geq 85 \%$ siswa mencapai KKM

b. Ketuntasan tujuan pembelajaran rata-rata mencapai $77,24 \%$ yakni telah memenuhi 
kriteria ketuntasan yakni $275 \%$ dari skor maksimum tiap butir soal.

c. Respon siswa terhadap pembelajaran diperoleh rata-rata $94,8 \%$,

d. Waktu pembelajaran dalam penelitian tidak berbeda jauh dengan waktu pembelajaran biasa.

2. Perangkat pembelajaran matematika berbasis PMR yang dikembangkan adalah efektif dalam meningkatkan motivasi siswa dengan ketuntasan klasikal mencapai $86,7 \%$ yakni telah memenuhi kriteria ketuntasan yakni $\geq 85 \%$ tuntas.

\section{UCAPAN TERIMA KASIH}

Pada kesempatan ini penulis ingin mengucapkan terima kasih yang tulus dan penghargaan yang setinggitingginya kepada semua pihak yang telah membantu penulis sampai terselesaikannya tesis ini.Semoga Yang Maha Kuasa membalas dengan kebaikan yang setimpal. Terima kasih dan penghargaan penulis sampaikan kepada:

1. Bapak Prof. Dr. Hasratuddin, M.Pd, selaku dosen pembimbing I dan Bapak Prof. Dr.. Edi Syahputra, M.Pd selaku dosen pemimbing II, yang telah meluangkan waktu disela-sela kesibukannya untuk memberikan bimbingan, arahan dan saran-saran yang sangat berarti bagi penulis dalam penyusunan tesis ini sampai selesai.

2. Bapak Prof. Dr. Edi Syahputra, M.Pd dan Bapak Dr. Mulyono, M.Si selaku ketua dan sekretaris Program Studi Pendidikan Matematika Pascasarjana UNIMED.

3. Bapak Dr. Mulyono, M.Si, Prof. Dr. Pargaulan Siagian, M.Pd, Dr. Elmanani Simamora, M.Si, selaku narasumber yang telah banyak memberikan masukan dan sumbangan pemikiran sehingga menambah wawasan pengetahuan penulis dalam penyempurnaan penulisan tesis ini.

4. Bapak Hendri Dalimunte, S.Pd,M.A selaku staf Prodi Pendidikan Matematika

5. Bapak Prof. Dr. Bornok Sinaga, M.Pd selaku Direktur Program Pascasarjana UNIMED yang telah memberikan kesempatan serta bantuan administrasi selama pendidikan di Universitas Negeri Medan.

6. Seluruh Bapak dan Ibu Dosen Pendidikan Matematika Program Pascasarjana UNIMED yang telah banyak memberikan ilmu pengetahuan yang sangat berharga bagi pengembangan wawasan keilmuan selama mengikuti studi dan penulisan tesis.

7. Kepala Sekolah SMP Negeri 2 Pulo Bandring serta guru-guru dan staf administrasi yang telah memberikan izin dan kesempatan kepada penulis untuk melakukan penelitian di sekolah tersebut.

8. Secara khusus dan istimewa penulis mengucapkan terima kasih dan hormat kepada Suami, Ayahanda \& Ibunda untuk semua kasih sayang, doa, motivasi, jerih payah serta dukungan penuh untuk setiap langkah dalam menyelesaikan perkuliahan dan penulisan tesis ini.

9. Adik-adik yang selalu mengharapkan kesuksesan saya.

10. Rekan-rekan mahasiswa seperjuangan Program Studi Pendidikan Matematika Program Pascasarjana Universitas Negeri Medan khususnya kelas B-1 angkatan XXV tahun 2016.

\section{REFERENSI}

Alkalbani, M.S. \& Alwahaibi, S.S. 2015. Testing the Multiple Intelligences Theory in Oman. Procedia - Social and Behavioral Sciences 190 ( 2015 ) 575 - 581.

Athar, G.A. 2012. Pengembangan Pembelajaran Matematika Dengan Pendekatan Pendidikan Matematika Realistik (PMR) Berbasis Budaya Cerita Rakyat Melayu Riau. Paper terseleksi dan dipublikasikan pada prosiding SemNasTika UNY, 2012.

Aufa, M; Saragih, S \& Minarni, A. 2016. Development of Learning Devices through Problem Based Learning Model Based on the Context of Aceh Cultural to Improve Mathematical Communication Skills and Social Skills of SMPN 1 Muara Batu Students. Volume 7, No.24,

Azwar \& Surya, E. 2017. Development of Learning Device Based Contextual Teaching and Learning Model Based on The Context of Aceh Cultural to Improve Mathematical Representation and self-efficacy of SMAN 1 Peureulak Students. Journal of Education and Practice, Vol 8, No 27.

Colomeischi, A.A. \& Colomeischi, T. 2015. The Students' Emotional Life and Their Attitude Toward Mathematics Learning. Procedia Social and Behavioral Sciences 174 ( 2015 ) $2818-2824$

Farida, I.; Herkulana \& Salim, I. 2015. Pengaruh Motivasi Belajar dan Pemanfaatan Sumber Belajar Terhadap Hasil Belajar Siswa SMP Negeri 11 Pontianak.

Fuadiah, N.F.; Zulkardi \& Hiltrimartin, C. 2009. Pengembangan Perangkat Pembelajaran Pada Materi Geometrid an Pengukuran Dengan Pendekatan Pendidikan Matematika Realistik Indonesia Di SD Negeri 179 Palembang. Jurnal Pendidikan Matematika, Volume 3, No. 2, Desember 2009.

Hadi, S. 2017. Pendidikan Matematika Realistik : Teori Pengembangan dan Implementasinya. Jakarta: PT Raja Grafindo Persada.

Hasratuddin. 2014. Pembelajaran Matematika Sekarang dan Yang Akan Datang Berbasis Karakter. Jurnal Didaktik Matematika, Vol. 1 No. 2 September 2014.

Marlina, M. 2013. Pengembangan Perangkat Pembelajaran Geometri SMP dengan Strategi 
Pembelajaran Kolaboratif. Jurnal Pendidikan Matematika, Volume 8-Nomor 2, Desember 2013.

Marpaung, Y. 2008. Pembelajaran Matematika Realistik. Disampaikan pada diklat peningkatan kompetensi matematika bagi guru SD, kerjasama Direktorat Pembinaan Profesi Dirjen PMPTK, di PPPG Matematika Yogyakarta.

Maier, P.H. 1998. Spatial geometry and spatial abilityHow to make solid geometry solid?. Selected Papers from the Annual Conference of Didactics of Mathematics 1996.

Murdani ; Johar, R \& Turmudi. 2013. Pengembangan Perangkat Pembelajaran Matematika Dengan Pendekatan Realistik Untuk Meningkatkan Penalaran Geometri Spasial Siswa Di SMP Negeri Arun Lhokseumawe. Jurnal Peluang, Vol. 1, No. 2, April 2013.

Nur, M. \& Surya, E. 2017. The Integration of Realistic Mathematical Approach And Virtual Manipulative As An Enhancement of Students' Mathematical

Noviani, J.; Syahputra, E. \& Murad, A. 2017. The Effect of Realistic Mathematic Education (RME) in Improving Primary School Students' Spatial Ability in Subtopic Two Dimension Shape. Journal of Education and Practice Vol. 8 No. 34

Oktaviana, R. 2016. Peran Kemampuan Spasial Siswa dalam Menyelesaikan Masalah Matematika yang Berkaitan dengan Geometri. Konferensi Nasional Penelitian Matematika dan Pembelajarannya (KNPMP I), Makalah Prosiding.

Pieronkiewicz, B. 2015. The Idea Of Diagnosis And Therapy Of Underachievement Syndrome In Learning Mathematics. Procedia - Social and Behavioral Sciences 191 ( 2015 ) 2416 - 2421

Prastyo, Y. 2017. Deskripsi Kemampuan Spasial Siswa SMP Ditinjau Berdasarkan Perbedaan Gender dan Kemampuan Matematika. Jurnal Ilmiah: SoulMat Vol 5, No 1, Oktober 2017.

Quintero, E.; Salinas, P; Mendivil, E.G. \& Ramirez, H. 2015. Augmented Reality app for Calculus: A Proposal for the Development of Spatial Visualization. Procedia Computer Science 75 ( 2015 ) $301-305$

Ritonga, E.M.; Surya, E. \& Syahputra, E. 2017. Development of Learning Devices Oriented Model Eliciting Activities to Improve Mathematical Problem Solving Ability Junior High School Student. International Journal of Sciences: Basic and Applied Research (IJSBAR) (2017) Volume 33, No 3, pp 42-52.

Shadiq, F. \& Mutajab, N.A. 2010. Pembelajaran Matematika dengan Pendekatan Realistik di SMP. Yogyakarta: Pusat Pengembangan dan Pemberdayaan Pendidik dan Tenaga
Kependidikan Matematika Departemen

Pendidikan Nasional.

Safitri, A.; Surya, E.; Syahputra, E. \& Simbolon, M. 2017. Impact of Indonesian Realistic Mathematics Approach to Students Mathematic Disposition on Chapter Two Composition Function and Invers Fungtion in Grade XI IA-1 SMA Negeri 4 Padangsidimpuan. International Journal of Novel Research in Education and Learning Vol. 4, Issue 2,( March - April 2017):93-100.

Sabrida, Y. 2016. Pengembangan Bahan Ajar Berbasis Budaya Dengan Pendekatan Realistik Untuk Meningkatkan Kemampuan Komunikasi dan Motivasi Belajar Siswa MTs YMPI Tanjung Balai. Thesis tidak diterbitkan. Medan: Sekolah Pasca Sarjana UNIMED Medan.

Sembiring, R.K. 2010. Pendidikan Matematika Realistik Indonesia (PMRI): Perkembangan dan Tantangannya. IndoMS. J.M.E Vol 1, No 1 Juli 2010, pp. 11-16

Syahputra, E. 2013. Peningkatan Kemampuan Spasial Siswa Melalui Penerapan Pembelajaran Matematika Realistik. Yogyakarta: Jurnal Cakrawala. November 2013

Sukmadinata, N.S. 2012. Metode Penelitian Pendidikan. Bandung: PT Remaja Rosdakarya.

Suranto. 2015. Pengaruh Motivasi, Suasana Lingkungan dan Sarana Prasarana Belajar Terhadap Prestasi Belajar Siswa (Studi Kasus Pada SMA Khusus Putri SMA Islam Diponegoro Surakarta). Jurnal Pendidikan Ilmu Sosial, Vol 25, No.2, Desember 2015

Tapantoko, A. A. 2011. Penggunaan Metode Mind Map (Peta Pikiran) Untuk Meningkatkan Motivasi Belajar Siswa Dalam Pembelajaran Matematika Siswa Kelas VIII SMP Negeri 4 Depok. Universitas Negeri Yogyakarta.

Tohidi, H. \& Jabbari, M.M. 2012. The Effect of Motivation in Education. Procedia - Social and Behavioral Sciences 31 ( 2012 ) 820 824

Wahyuni, R.; Putri, R.I.I. \& Hartono, Y. 2015. Volume Kubus dan Balok Melibatkan Kemampuan Visualisasi Spasial Di Kelas VIII. Vol 1 No 2, hal 41-51.

Zulfahmi.; Syahputra, E. \& Fauzi, K.M.A. 2017. Development of Mathematics Learning Tools Based Van Hiele Model to Improving Spatial Ability and Self-Concept Student's of MTs.S Ulumuddin. American Journal of Education Research, 2017, Vol.5, No.10,1080-1086. 